\title{
Assessment of sustainable non-plantation biomass resources potential for energy in India
}

\author{
N.H. Ravindranath ${ }^{\mathrm{a}, *}$, H.I. Somashekar ${ }^{\mathrm{a}}$, M.S. Nagaraja ${ }^{\mathrm{a}}$, P. Sudha ${ }^{\mathrm{a}}$, \\ G. Sangeetha ${ }^{a}$, S.C. Bhattacharya ${ }^{b}$, P. Abdul Salam ${ }^{b}$ \\ ${ }^{a}$ Centre for Sustainable Technologies, Indian Institute of Science, Bangalore, India \\ ${ }^{\mathrm{b}}$ Energy Field of Study, School of Environment, Resources and Development, Asian Institute of Technology, P.O. Box 4, \\ Klongluang, Pathumthani 12120, Thailand
}

\begin{abstract}
In India, fuelwood, crop residues and animal manure are the dominant biomass fuels, which are mostly used in the rural areas, at very low efficiencies. Industrial and municipal (urban) residues such as wastewater, municipal solid wastes (MSW), and crop residues such as rice husk and bagasse can also be used for energy generation. In this paper, the potential of energy from crop residues, animal manure, MSW, industrial wastewater and biomass fuels that can be conserved for other applications through efficiency improvement is discussed. The total potential of energy from these sources in 1997 is estimated to be equivalent to 5.14 EJ, which amounts to a little more than a-third of the total fossil fuel use in India. The energy potential in 2010 is estimated to be about 8.26 EJ.
\end{abstract}

Keywords: Animal manure; Biomass; Fuelwood conservation and substitution; Sustainable energy

\section{Introduction}

In India, biomass fuels dominate the rural energy consumption patterns, accounting for over $80 \%$ of total energy consumed [1]. Fuelwood, crop residues (including plantation crops) and livestock dung are the biomass fuels used in rural areas. Fuelwood is the preferred and most dominant

\footnotetext{
*Corresponding author. Tel.: +91 8023601455 ; fax: +918023601428 .

E-mail address: ravi@ces.iisc.ernet.in (N.H. Ravindranath).
}

biomass source accounting for $54 \%$ of biofuels used in India [1]. Scarcity and increasing prices of fuelwood have been altering the biofuel consumption pattern. Due to scarcity of fuelwood, people are shifting to dung and various crop residues. The use of biofuels in domestic devices is associated with drudgery and adverse health impacts on women [2]. In most rural houses, the fuel use efficiency in domestic devices, particularly cook stoves, is low, in the range of $10-14 \%$ [1]. Thus, improving the conversion efficiency would be a significant step towards improving the quality of 
life and environment. Efforts are already under way to promote efficient devices and alternate energy sources for improving the quality of life and conserving biomass resources.

The urban energy demand in India is largely met by modern sources of energy such as electricity, LPG and kerosene. The urban population accounts for nearly one-fourth $(25.7 \%)$ of the total population and is growing at a faster rate than the rural population in India. The population in the urban areas is likely to double by 2010, while the quantity of Municipal Solid Wastes (MSW) generated is expected to triple [3]. Thus, the disposal of solid and liquid streams is one of the major emerging environmental problems of urban India and requires large investments. As significant part of these materials is organic in nature, they could be effectively harnessed as feedstock for producing gaseous fuel and electricity. With growing industrialization, the industrial residue generation has also been growing; these could also be harnessed for energy generation.

The biofuel usage has changed over the years, particularly in urban areas. Even though there has been a shift from biomass fuels to fossil fuels and electricity in the urban region, the annual biofuel consumption in domestic sector at the national level is still high and has increased continuously from 206 million tonne (Mt) during 1953-54 to $383 \mathrm{Mt}$ in 1996-97. Fuelwood meets more than half of the energy requirements for cooking and domestic water heating in the rural households while, it accounts for about one-third of the energy requirement in urban households [4]. Dung cake accounts for about $4 \%$ and $21 \%$ of the urban and rural energy requirements, respectively. Use of crop residues is restricted only to the rural areas as they are not available in the urban centres. Even though the share of biomass fuels in the national energy use is declining, the magnitude of fuelwood, crop residues and even cattle dung is projected to increase [5].

\section{Sustainable national biomass resource potential}

It is important to estimate total crop residue, cattle dung, MSW and industrial wastewater generated annually, their current usage levels and potential surplus available for energy use. Hence, the focus of this paper is to assess the energy potential of biomass resources in the form of residues and wastes, i.e. biomass from nonplantation sources in India with the following specific objectives: (i) to estimate total crop residue, cattle dung, MSW and industrial wastewater production, (ii) to estimate the fraction of crop residue, cattle dung and MSW, industrial wastewater available as energy source, and (iii) to assess the fuelwood conservation and substitution potential through shift to improved stove and kerosene/LPG, respectively.

The methodologies used to estimate the energy potential of the biomass sources are presented elsewhere [6].

\subsection{Agricultural crop residues}

For assessing the crop residues for energy potential it is imperative to understand the area under agricultural crops, cropping patterns and utilization of crop residues.

\subsubsection{Area under agricultural crops and cropping pattern}

In India, out of the total geographic area of 328 million hectare (Mha), the net cropped area accounts for about $43 \%$ and it appears that the net cropped area has stabilized around 140 Mha since 1970 [7]. However, the gross cropped area has increased from 152.8 Mha in 1960 to about 168.6 Mha in 1996-97 and is likely to reach 178.2 Mha by 2010. In India there are two main cropping seasons, namely Kharif (based on southwest monsoon) and Rabi (north-east monsoon). Gross cropped area includes land areas subjected to multiple cropping (normally double cropping) in irrigated land. Net irrigated area has increased substantially from 24 Mha during 1960-61 to 55 Mha by 1996-97. Rice and wheat are the dominant crops, together accounting for $41 \%$ of cropped area, while pulses, oil seeds and other commercial crops account for $13.8 \%, 15.9 \%$ and $10.2 \%$, respectively. Cereals dominate the agricultural crops as shown in Table $1[8,9]$ and account 
for $60 \%$ of cropped area, followed by pulses, cotton and sugarcane.

Out of 140 Mha of net-cropped area, more than $50 \%$ is estimated to become irrigated by 2010 . It has been observed that the adoption of irrigation practices results in expansion of crops such as rice, wheat, cotton and sugarcane. It is estimated that expansion of irrigation by 2010 may result in increase of area under the above said crops by $6 \%$ ( $>10 \mathrm{Mha}$ ) at the cost of coarse cereals and millets. These changes would also influence production of crop residues in the future.

\subsubsection{Agricultural crop residue production}

The residue production varies from crop to crop. The data on the residue to product ratio (RPR) are given in Table 1. The straw to grain ratio of the cereals varies from 2.5 for maize to 1.6 for wheat. Straw, a low-density residue, is the dominant residue. Rice husk, a by-product of rice milling, accounts for $20 \%$ of paddy. Unlike the cereals, crops such as red gram, cotton, rapeseed, mustard, mulberry and plantation crops produce woody (ligneous) residues. Residue production for mulberry, coconut and sugarcane were estimated based on field studies [1,9].

The total crop residue production in India during 1996-97 is estimated to be $626 \mathrm{Mt}$ of air dry weight (Table 1). The dominant residues are those of rice, wheat, sugarcane and cotton accounting for $66 \%$ of the total residue production. Sugarcane and cotton residue production is 110 and $50 \mathrm{Mt}$, respectively.

\subsubsection{Current use of crop residues}

The use of crop residues varies from region to region and depends on their calorific values, lignin content, density, palatability and nutritive value. Residues of most of the cereals and pulses have fodder value. However, woody nature of residues of a few crops restricts their use to fuel purpose only. The dominant end uses of crop residues in India are as fodder for cattle, fuel for cooking and thatch material for housing.

India has a large cattle population of 294 million. Even though India has 67 Mha of grazing land, grass productivity is low due to land degradation, leading to near total dependence of cattle on crop residues of cereals and pulses. The estimated total residues utilized as fodder was $301 \mathrm{Mt}$ in 1996-97 and is projected to be $385 \mathrm{Mt}$ for 2010, accounting for about $47 \%$ of total residues generation as shown in Table $2[8,9]$. Use of some crop residues as fodder is the priority in rural areas and only ligneous residues are likely to be available for use as an energy source.

In India, dung use as fuel is wholly restricted to the domestic sector, while crop residues are used as fuel in both domestic and industrial sectors. Ligneous and hardy crop residues namely, rice (husk), maize (cobs) and stalks of redgram, cotton, mulberry, coconut fronds and shells are mainly used for fuel purpose. About $44 \mathrm{Mt}$ of sugarcane bagasse is used as fuel in sugar mills, and in smallscale crude rural sugar producing units. The total residue use as a fuel in India during 1996-97, as indicated in Table 2, is estimated to be $216 \mathrm{Mt}$ and the projected value for 2010 is $278 \mathrm{Mt}[9,10]$. Reported estimates of different types of biomass used as fuel is given in Table $3[1,5,11]$.

In addition to use of crop residues as fuel and fodder, the residue of some crops are used for thatching, composting, mulching, etc. Rice and wheat straw, and coconut fronds are used to a small extent for thatching in the rural areas. Non-woody leguminous crop residues are normally put into the composting pit after the harvest of the main produce. The leafy residue of sugarcane is burnt in the field. The total crop residue used for other purposes amounted to $109 \mathrm{Mt}$ in $1996-97$ and is projected to rise to $172 \mathrm{Mt}$ by 2010 (Table 2).

\subsubsection{Availability of crop residues for energy generation}

Crop residues, which are used as fodder, will not be available as feedstock for energy. The total potential of non-fodder crop residues available for energy is estimated to be 325 and $450 \mathrm{Mt}$ for 1996-97 and 2010, respectively (Table 4). Only the woody (ligneous) crop residues, rice husk and bagasse are considered for energy.

\subsection{Animal manure}

India has the world's largest bovine population and recorded 294 million during 1996-97 
Table 1

Area under different crops and their respective residue production in India

\begin{tabular}{|c|c|c|c|c|c|c|c|c|c|c|c|}
\hline \multirow[t]{2}{*}{ Crop } & \multirow[t]{2}{*}{ Economic produce } & \multicolumn{3}{|l|}{ 1996-97 } & \multicolumn{3}{|l|}{2010} & \multirow{2}{*}{$\begin{array}{l}\text { Residue to final } \\
\text { economic } \\
\text { produce ratio }\end{array}$} & \multirow[t]{2}{*}{ Type of residue } & \multicolumn{2}{|c|}{ Moisture \% } \\
\hline & & $\begin{array}{l}\text { Gross } \\
\text { cropped area } \\
\text { (Mha) }\end{array}$ & $\begin{array}{l}\text { Total } \\
\text { economic } \\
\text { production } \\
\text { (Mt) }\end{array}$ & $\begin{array}{l}\text { Total residue } \\
\text { production } \\
\text { Mt (air dry) }\end{array}$ & $\begin{array}{l}\text { Gross } \\
\text { cropped area } \\
\text { (Mha) }\end{array}$ & $\begin{array}{l}\text { Total } \\
\text { economic } \\
\text { production } \\
\text { (Mt) }\end{array}$ & $\begin{array}{l}\text { Total residue } \\
\text { production } \\
\text { Mt (air dry) }\end{array}$ & & & $\begin{array}{l}\text { At } \\
\text { harvest }\end{array}$ & $\begin{array}{l}\text { At } \\
\text { use }\end{array}$ \\
\hline Rice & Food grain & 43.3 & 81.3 & 146.5 & 46.1 & 118.8 & 213.9 & 1.8 & Straw + husk & 30 & 10 \\
\hline Wheat & Food grain & 25.9 & 69.3 & 110.6 & 28.5 & 98.5 & 157.6 & 1.6 & Straw & 30 & 10 \\
\hline Jowar & Food grain & 11.6 & 11.0 & 22.3 & 5.3 & 6.1 & 12.2 & 2.0 & Stalk & 30 & 10 \\
\hline Bajra & Food grain & 10.0 & 7.9 & 15.8 & 8.6 & 6.8 & 13.6 & 2.0 & Stalk + cobs & 30 & 10 \\
\hline Maize & Food grain & 6.2 & 10.6 & 26.3 & 6.6 & 13.0 & 32.5 & 2.5 & Straw & 30 & 10 \\
\hline Other cereals & Food grain & 4.3 & 4.7 & 9.4 & 1.3 & 1.4 & 2.8 & 2.0 & Stalk & 30 & 10 \\
\hline Red gram & Food grain & 3.6 & 2.7 & 13.5 & 3.6 & 2.7 & 11.2 & 5.0 & Waste & 20 & 10 \\
\hline Gram & Food grain & 7.1 & 5.7 & 9.3 & 7.7 & 7.0 & 13.5 & 1.6 & Waste & 20 & 10 \\
\hline Other pulses & Food grain & 12.5 & 5.8 & 17.1 & 12.5 & 5.9 & 17.1 & 2.9 & Shell + waste & 20 & 10 \\
\hline Ground nut & Oil seed & 7.9 & 9.0 & 20.7 & 9.3 & 12.2 & 28.1 & 2.3 & Waste & 30 & 10 \\
\hline Rape seed \& mustard & Oil seed & 6.9 & 6.9 & 13.8 & 10.7 & 12.0 & 24.1 & 2.0 & Waste & 20 & 10 \\
\hline Other oil seeds & Oil seed & 12.1 & 9.1 & 18.2 & 18.0 & 13.5 & 27.1 & 2.0 & Waste & 20 & 10 \\
\hline Cotton & Fiber & 9.1 & 14.3 & 50.0 & 10.1 & 15.9 & 55.7 & 3.5 & Seeds + waste & 20 & 10 \\
\hline Jute & Fiber & 0.9 & 9.8 & 15.7 & 0.6 & 6.5 & 10.5 & 1.6 & Waste & 30 & 10 \\
\hline Sugar cane & Sugar & 4.2 & 277.2 & 110.8 & 5.5 & 463.5 & 185.4 & 0.4 & Bagasse + leaves & 30 & 30 \\
\hline Coconut + arecanut & Oil + confectionery & 2.0 & - & 20.0 & 2.8 & - & 28.2 & $10 \mathrm{tha}^{-1} \mathrm{yr}^{-1}$ & Fonts & 20 & 10 \\
\hline Mulberry & Silk fiber & 0.3 & - & 3.0 & 0.3 & - & 3.3 & $10 \mathrm{tha}^{-1} \mathrm{yr}^{-1}$ & Sticks & 20 & 10 \\
\hline Coffee + tea & Beverage & 0.7 & 0.8 & 3.42 & 0.8 & 1.0 & 3.9 & 4.0 & Twigs + branch & 30 & 10 \\
\hline Total & & 168.6 & & 626.5 & 178.2 & & 840.6 & & & & \\
\hline
\end{tabular}

Source: $[8,9]$.

Note: (1) Horticultural crops occupying in smaller area is not accounted. (2) For the year 2010, the area and productivity are projected based on the data from 1951 to 1995.

(3) Sugar cane biomass accounted for leaves and bagasse. 
Table 2

Quantity of agricultural residues used as fodder, fuel and for other purposes in India (Mt)

\begin{tabular}{|c|c|c|c|c|c|c|}
\hline \multirow[t]{2}{*}{ Crop } & \multicolumn{3}{|l|}{$1996-97$} & \multicolumn{3}{|l|}{2010} \\
\hline & Fodder & Fuel & Others $^{\mathrm{a}}$ & Fodder & Fuel & Other $^{\mathrm{a}}$ \\
\hline Rice & 119.9 & 16.3 & 10.4 & 173.0 & 23.8 & 17.2 \\
\hline Wheat & 101.8 & 0 & 8.8 & 136.2 & 0.0 & 21.4 \\
\hline Jowar & 22.3 & 0 & 0 & 12.3 & 0.0 & 0.0 \\
\hline Bajra & 15.8 & 0 & 0 & 12.3 & 0.0 & 1.4 \\
\hline Maize & 21.1 & 5.3 & 0 & 26.4 & 6.2 & 0.0 \\
\hline Other cereals & 9.4 & 0 & 0 & 2.8 & 0.0 & 0.0 \\
\hline Red gram & 0 & 13.5 & 0 & 0.0 & 8.8 & 2.4 \\
\hline Gram & 0 & 7.3 & 2.0 & 0.0 & 13.5 & 0.0 \\
\hline Other pulses & 0 & 8.6 & 8.5 & 0.6 & 8.3 & 8.2 \\
\hline Ground nut & 0 & 4.1 & 16.6 & 0.0 & 3.7 & 24.4 \\
\hline Rape seed and mustard & 0 & 13.8 & 0 & 0.0 & 24.1 & 0.0 \\
\hline Other oil seeds & 0 & 18.2 & 0 & 0.0 & 27.1 & 0.0 \\
\hline Cotton & 0 & 50.0 & 0 & 0.0 & 55.7 & 0.0 \\
\hline Jute & 0 & 15.7 & 0 & 0.0 & 5.9 & 0.0 \\
\hline Sugarcane $^{\mathrm{b}}$ & 11.1 & 44.3 & 55.4 & 21.9 & 76.0 & 87.5 \\
\hline Coconut + arecanut & 0 & 16.0 & 4.0 & 0.0 & 22.6 & 5.6 \\
\hline Mulberry & 0 & 3.0 & 0 & 0.0 & 3.3 & 0.0 \\
\hline Coffee + tea & 0 & 0 & 3.4 & 0.0 & 0.0 & 3.9 \\
\hline Total & 301.4 & 216.1 & 109.2 & 385.4 & 278.7 & 172.0 \\
\hline
\end{tabular}

Source: $[8,9]$.

${ }^{a}$ Others include biomass used for composting, left in the field for thatching, etc.

${ }^{\mathrm{b}}$ Sugarcane biomass includes for both leaves and bagasse on dry weight basis.

Table 3

Biomass use as fuel in India (Mt)

\begin{tabular}{|c|c|c|c|c|c|c|c|c|c|}
\hline \multirow[t]{2}{*}{ Reference } & \multicolumn{3}{|c|}{ Fuelwood } & \multicolumn{3}{|c|}{ Crop residues } & \multicolumn{3}{|c|}{ Dung } \\
\hline & 1990 & 1995 & 2010 & 1990 & 1995 & 2010 & 1990 & 1995 & 2010 \\
\hline FAO [11] & 172 & 197 & 241 & - & - & - & - & - & - \\
\hline Sarma et al. $[5]^{\mathrm{a}}$ & - & 214 & 381 & - & 67 & 132 & - & 64 & 98 \\
\hline Ravindranath and Hall [1] & 298 & - & - & 156 & - & - & 114 & - & - \\
\hline
\end{tabular}

${ }^{a}$ Only combustible crop residues and dung used as dung cake are accounted.

(including cows, bullocks, buffaloes and calves), with cattle to human population ratio of 0.3 . Cattle accounts for more than two-thirds of the bovine population, while buffalo account for $28.6 \%[1,12,13]$. The population of goat and sheep is 169 million. Estimated populations of cattle and buffalo for 2010 are 224 and 97 million, respectively. Interestingly, the piggery and poultry industry has grown substantially in the last two decades in an organized way and hence manure from these would have a great potential for energy in the future.

Dung production depends on the cattle population and dung yield per animal. All the dung produced by cattle is difficult to collect and use. In India, the cattle are allowed to graze in open fields and hence, dung produced during grazing and working periods cannot be collected. Bullocks are 
largely used as draft animals for agricultural operations including rural transport and the dung cannot be collected. Hence, the dung collection would be mostly from droppings at the cattle sheds. Improved cows and buffalo are reared for milk production and generally stall-fed; thus, the dung collection efficiency is higher. Dung yield varies with breeds, animal, age, region and season.

Table 4

Amount of non-fodder crop residues potentially available for energy use

\begin{tabular}{lcrrrr}
\hline Crop & \multicolumn{2}{c}{$1996-97$} & & \multicolumn{2}{c}{2010} \\
\cline { 2 - 3 } \cline { 6 - 6 } & Mt & PJ & & Mt & \multicolumn{1}{c}{ PJ } \\
\hline Rice & 26.7 & 347 & & 41 & 532 \\
Wheat & 8.8 & 115 & & 21.4 & 278 \\
Bajra & 0 & 0 & & 1.4 & 18 \\
Maize & 5.3 & 69 & & 6.2 & 80 \\
Red gram & 13.5 & 176 & & 11.2 & 145 \\
Gram & 9.3 & 121 & & 13.5 & 176 \\
Other pulses & 17.1 & 222 & & 16.5 & 215 \\
Ground nut & 20.7 & 284 & & 28.1 & 384 \\
Rape seed and mustard & 13.8 & 189 & & 24.1 & 330 \\
Other oil seeds & 18.2 & 249 & & 27.1 & 371 \\
Cotton & 50 & 750 & & 55.7 & 835 \\
Jute & 15.7 & 235 & & 5.9 & 88 \\
Sugarcane & 99.7 & 1562 & & 163.5 & 2581 \\
Coconut + arecanut & 20 & 300 & & 28.2 & 423 \\
Mulberry & 3 & 45 & 3.3 & 50 \\
Coffee + tea & 3.4 & 51 & 3.9 & 59 \\
& & & & \\
Total & 325.3 & 4715 & 450.7 & 6565 \\
\hline
\end{tabular}

Based on mean annual average dung yield (fresh weight) of $4.5 \mathrm{~kg} \mathrm{day}^{-1}$ for cattle and $10.2 \mathrm{~kg} \mathrm{day}^{-1}$ for buffalo, total dung production is estimated to be $659 \mathrm{Mt}$ annually, with cattle dung accounting for $344 \mathrm{Mt}$ and buffalo dung accounting for $315 \mathrm{Mt}$ as shown in Table 5 [12]. The corresponding dung produced from cattle and buffalo for 2010 is estimated to be 368 and $362 \mathrm{Mt}$, respectively with a total dung production of $730 \mathrm{Mt}$. The data on availability of animal manure from pig and poultry sectors are not available and not considered in this study. The dung collection efficiency of sheep and goat is assumed to be zero.

\subsubsection{Current dung usage and availability of dung for energy generation}

The data on the present usage of dung and potential availability for various purposes are given in Table 6 . About $185 \mathrm{Mt}, 40 \%$ of the dung collected is used as fuel in cookstoves. The quantity of dung used annually in the existing 2.7 million family type biogas plants - assuming 5 animals per plant is estimated to be $22 \mathrm{Mt}$. Cattle dung use for biogas has large potential for the future, as only $22 \%$ of the total potential for biogas plants is being utilized [14]. Thus, the quantity of dung unused amounts to $251 \mathrm{Mt}$. If the potential of 12 million family biogas plants, is built by 2010 at the rate of one million annually, 98.5 Mt of dung produced could be used for biogas production. Rest of the dung is likely to be used as manure for crop production.

Table 5

Livestock population, dung production and its availability in India

\begin{tabular}{|c|c|c|c|c|c|c|}
\hline \multirow{2}{*}{$\begin{array}{l}\text { Year } \\
\text { Animals }\end{array}$} & \multicolumn{3}{|c|}{ 1996-97 } & \multicolumn{3}{|l|}{2010} \\
\hline & Cattle & Buffalo & Total & Cattle & Buffalo & Total \\
\hline Population (million) $)^{\mathrm{a}}$ & 209 & 84 & 294 & 224 & 97 & 321 \\
\hline Dung production $\left(\mathrm{kg} \mathrm{head}^{-1} \mathrm{day}^{-1}\right)$ & 4.5 & 10.2 & & 4.5 & 10.2 & \\
\hline Total dung produced $\left(\mathrm{Mt} \mathrm{yr}^{-1}\right)$ & 344 & 315 & 659 & 368 & 362 & 730 \\
\hline Dung recoverable percentage $(\%)$ & 60 & 80 & & 60 & 80 & \\
\hline Total dung recoverable $\left(\mathrm{Mt} \mathrm{yr}^{-1}\right)^{\mathrm{b}}$ & 206 & 252 & 458 & 221 & 289 & 510 \\
\hline
\end{tabular}

Source: $[1,12,13]$.

${ }^{\mathrm{a}}$ Population data projected for 2010 using past trends.

${ }^{\mathrm{b}}$ Air dry weight. 
Table 6

Energy equivalents of available dung as cooking fuel and for power generation

\begin{tabular}{lcc}
\hline Energy equivalents of available dung & 1997 & 2010 \\
\hline Estimated dung production (Mt) & 659 & 730 \\
Total dung recoverable (Mt) & 510 \\
Dung directly utilized as fuel (Mt) & 185 & 251 \\
Total dung unutilized and available for energy (Mt) & 2.7 \\
Family size biogas plants (Million) & 22 & 12.0 \\
Dung utilized in the biogas plants (Mt) (2.7 and 12 million plants, respectively) & 98.5 \\
Biogas produced (Mm ${ }^{3}$ ) (with 2.7 and 12 million biogas plants, respectively) & 780 \\
Energy equivalents of biogas produced (PJ) (from 22 and 98 Mt of dung, respectively) & 17.9 \\
Biogas potential (Mm ${ }^{3}$ ) (if all collectable dung used for biogas, i.e. 458 Mt in 1997 and 510 Mt in 2010) & 16030 \\
Energy potential of biogas produced (PJ) & 3448 \\
\hline
\end{tabular}

The potential for family biogas plants in India is 12-17 million, but only 3.65 million plants had been built by 2003. Thus a large potential for family biogas is yet to be utilized. With the existing technology, the potential for biogas production annually is 8750 million $\mathrm{m}^{3}$ (from $251 \mathrm{Mt}$ of dung). This biogas could be used directly as cooking fuel $(183 \mathrm{PJ})$ or for generation of $11.67 \mathrm{GWh}$ of electricity annually.

\subsection{Fuelwood saving through efficiency improvement and fuel switching}

Fuelwood is the dominant fuel consumed in rural India. Dependency on fuelwood has consequences, firstly on environment due to nonsustainable extraction from forests, village commons and farms and secondly, on health and quality of life of women. Many projections indicate that rural communities would continue to depend on biofuels in the future while, in urban areas use of biofuels is likely to be insignificant as urban households have access to LPG, kerosene and electricity [1,5]. The scarcity of fuelwood, associated with its high price, necessitates conservation through use of efficient stoves and switch over to other fuels. Hence, in this section, the fuelwood conservation potential through shifting to efficient stoves is estimated by considering only rural households. The feasibility of different biomass conservation options is also discussed in this section. Energy required, efficiency of the fuel-device combinations and fuelwood conservation potential is given in Table $7[9,15,16]$.

\subsubsection{Fuelwood conservation potential of improved stoves}

The traditional cookstoves using fuelwood have low thermal efficiencies of about $14 \%$ [1,17]. Efficient stove designs with over $30 \%$ of thermal efficiency are available and are being intensively implemented in India (Table 7). Field studies have shown that use of efficient stoves results in only about $20 \%$ saving of fuelwood compared with traditional stoves due to variation in cooking practices, inadequate user education, lack of repair and improper construction of improved stoves [15]. Nearly $50 \%$ of the improved stoves built are non-functional due to physical damage or poor maintenance. The total number of rural households projected to be covered under LPG (13.4 million), kerosene (20.1 million), family biogas ( 8.2 million) and community biogas (0.031 million) is 42 million by 2010 . Thus, all the remaining 89.2 million households could be potentially covered under the improved stove programme. Based on the projected rates of dissemination, the fuel conservation potential of improved cookstoves is estimated to be $25.7 \mathrm{Mt}$ annually by 2010 (Table 8).

\subsubsection{Fuelwood conservation potential in industrial sector}

The industrial biomass use in India include: rice husk use in small restaurants, brick firing and rice 
Table 7

Energy required, efficiency of device and fuelwood conservation potential

\begin{tabular}{lllr}
\hline Device & $\begin{array}{l}\text { Consumption } \\
\left(\mathrm{kg} \mathrm{HH}^{-1} \mathrm{yr}^{-1}\right)\end{array}$ & $\begin{array}{l}\text { Thermal efficiency } \\
\text { of device (\%) }\end{array}$ & $\begin{array}{l}\text { Fuelwood } \\
\text { conservation potential } \\
\left(\mathrm{kg} \mathrm{HH}^{-1} \mathrm{yr}^{-1}\right)\end{array}$ \\
\hline Traditional cookstove & 1800 & 14 & 360 \\
Efficient cookstove & 1440 & 33 & 1800 \\
Kerosene stove & 159 & 60 & 1800 \\
LPG & 120 & 60 & \\
\hline
\end{tabular}

Source: [18].

Note: $\mathrm{HH}$ - household.

Table 8

Conservation potential by shifting from fuelwood to improved stoves

\begin{tabular}{lllll}
\hline Technology & By year 2010 & Method of estimation & \\
\cline { 2 - 4 } & $\begin{array}{l}\text { No of units } \\
\text { (Million) }\end{array}$ & $\begin{array}{l}\text { Operational } \\
\text { units }(\%)\end{array}$ & $\begin{array}{l}\text { Fuelwood } \\
\text { conservation }(\mathrm{Mt})\end{array}$ & \\
\hline Improved stoves & 89.2 & 80 & 25.7 & $\begin{array}{l}89.2 \text { million stoves } \times 1.8 \mathrm{t} \mathrm{HH}^{-1} \mathrm{yr}^{-1} \times 80 \% \text { of stoves } \\
\text { operational } \times 20 \% \text { reduction in fuelwood use }\end{array}$
\end{tabular}

Source: [15].

Note: Rural households-114 million in 1990 and 134 million by 2010 .

parboiling; sugarcane bagasse use as fuel in sugar mills and jaggery (crude sugar) manufacturing units; and fuelwood for brick industry in rural areas and in urban establishments.

Fuelwood use in industrial sector is largely for brick industries and in urban establishments. Based on the current utilization pattern of biomass in energy sector, the overall efficiency of utilization is in the range of $10-15 \%$, while utilization efficiencies in excess of $25 \%$ can easily be achieved. Thus, the savings could be up to $50 \%$ [1] compared to the prevailing situation. The total fuelwood use in the industrial sector is estimated to be $16 \mathrm{Mt}$. The fuelwood conservation potential by shifting to improved brick kilns is estimated to be $8 \mathrm{Mt}$ (120 PJ) (Table 9).

\subsubsection{Fuelwood substitution potential of kerosene}

A national level study estimated that during $1991,7.1 \%$ (8 million) of rural and $23.6 \%$ of urban households were dependent on kerosene for cooking $[9,18]$. Though, the first cost of biomassfired stove is low, its use in urban areas is restricted due to high cost of biomass fuels compared to conventional fuels and poor supply or distribution network. With increase in rural incomes, about $15 \%$ of households ( 20.1 million) are projected to shift to kerosene for cooking from biofuels. Thus, the fuelwood conservation potential of shifting to kerosene is $36 \mathrm{Mt}$ annually by 2010 (Table 10).

\subsubsection{Fuelwood substitution potential of $L P G$}

LPG is an ideal fuel for cooking. Currently, it is restricted to urban areas (27\% of households). In the absence of LPG supply and servicing network and its shortages, it is unlikely that rural households will have access to LPG in the near future $[9,18]$. Further, high initial cost of cylinder and stove is beyond the reach of majority of rural households. However, about $10 \%$ of rural households on the fringes of urban centres may shift to LPG by the end of the decade. The annual 
Table 9

Biomass conservation potential in industrial sector of India

\begin{tabular}{lllll}
\hline Biomass & Quantity used (Mt) & Potential for improvement (\%) & \multicolumn{2}{c}{ Potential for conservation (Mt) } \\
\cline { 3 - 5 } & & Mt & PJ \\
\hline Fuelwood $^{\mathrm{a}}$ & 16 & 50 & 8 & 120 \\
\hline
\end{tabular}

Source: [1].

${ }^{\mathrm{a}}$ Fuelwood use includes $6 \mathrm{Mt}$ for brick industry in rural areas and $10 \mathrm{Mt}$ in urban fuelwood use in establishments.

Table 10

Substitution potential of shifting from fuelwood to LPG and kerosene

\begin{tabular}{llll}
\hline Fuel & $\begin{array}{l}\text { No of households } \\
\text { likely to shift } \\
\text { by } 2010 \text { (million) }\end{array}$ & $\begin{array}{l}\text { Fuelwood } \\
\text { conserved (Mt) }\end{array}$ & Method of estimation \\
\hline LPG & 13.4 & 24 & 13.4 million $\mathrm{HH} \times 1.8 \mathrm{t}$ fuelwood $\mathrm{HH}^{-1} \mathrm{yr}^{-1}$ \\
Kerosene & 20.1 & 36 & 20.1 million $\mathrm{HH} \times 1.8 \mathrm{t}$ fuelwood $\mathrm{HH}^{-1} \mathrm{yr}^{-1}$ \\
\hline
\end{tabular}

Note: Rural households-114 million in 1990 and 134 million by 2010 .

fuelwood conservation potential would be $24 \mathrm{Mt}$ by shifting from conventional wood stoves to LPG by 2010 (Table 10).

The total fuelwood substitution potential of kerosene and LPG, assuming moderate growth rate is $60 \mathrm{Mt}$ annually by 2010 .

\subsection{Municipal solid wastes}

Generation of municipal wastes is not significant in rural areas. In this paper, we have considered the energy potential of solid waste generated by urban population only.

Municipal solid waste is normally collected, transported and dumped in the outskirts of towns and cities. Though sorting out for the recyclable materials by the rag pickers is common, other ways of handling, like composting, incineration, etc., also take place to some extent. The total quantity of solid wastes generated in larger towns and cities has been estimated at $20.7 \mathrm{Mt}$ annually for an urban population of 217 million in 1991. This is expected to increase to $40 \mathrm{Mt}$ by 2001 and reach $56 \mathrm{Mt}$ by 2010 [19] as the urban population is increasing at a decadal growth rate of above $40 \%$. The quantity of wastes generated per family in a week has also increased substantially from $7 \mathrm{~kg}$ during 1980 s to $20-30 \mathrm{~kg}$ at present. The data from Table 11 reveals that MSW production per capita increases with the size of the urban centre and is highest for cities with a population greater than 5 million. In India, based on 1991 census data, the estimated quantity of MSW generated in 10 major cities is more than $10 \mathrm{Mt}$ annually. The disposal of such huge quantities has become a major problem. Thus, the utilization of MSW for energy would mean a solution of this problem.

The MSW consists of glass, metal, paper, rubber, and other combustible organic matter. The organic matter component is of relevance to energy, particularly biomethanation. Paper plus other combustible matters together account for nearly $50 \%$ of MSW in urban areas [20].

\subsubsection{Energy from landfill gas ( $L F G$ )}

According to the Central Pollution Control Board (CPCB), the area under landfills in India has increased from 120 ha in 1947 to 20,200 ha in 1997. Unlike developed countries, in developing countries like India, the landfill system is not very prominent and well managed. Hence, it is not practicable to collect the methane, which escapes 
Table 11

Quantity of MSW generated (collected) annually in India

\begin{tabular}{|c|c|c|c|c|}
\hline $\begin{array}{l}\text { Population range } \\
\text { (Million) }\end{array}$ & $\begin{array}{l}\text { MSW per capita } \\
\left(\mathrm{kgcapita}^{-1} \mathrm{day}^{-1}\right)\end{array}$ & Towns & $\begin{array}{l}\text { MSW per town } \\
\text { wet wt (kt) [22] }\end{array}$ & $\begin{array}{l}\text { At national level } \\
\text { wet wt }(\mathrm{Mt})\end{array}$ \\
\hline $0.1-0.5$ & 0.21 & 272 & $33 \pm 2$ & 9.0 \\
\hline $0.5-1.0$ & 0.25 & 32 & $63 \pm 11$ & 2.0 \\
\hline $1.0-2.0$ & 0.27 & 15 & $120 \pm 24$ & 1.8 \\
\hline $2.0-5.0$ & 0.35 & 5 & $417 \pm 128$ & 2.1 \\
\hline$>5$ & 0.50 & 5 & $1729 \pm 499$ & 8.6 \\
\hline Total & & 329 & & 23.5 \\
\hline
\end{tabular}

Table 12

Energy potential from landfill gas of MSW

\begin{tabular}{llllll}
\hline $\begin{array}{l}\text { MSW generated } \\
\left(\mathrm{Mt} \mathrm{yr}^{-1}\right)\end{array}$ & $\begin{array}{l}\text { Quantity land } \\
\text { filled @ 0.85\% of } \\
\text { total MSW } \\
\left(\mathrm{Mt} \mathrm{yr}^{-1}\right)\end{array}$ & $\begin{array}{l}\text { DOC content in } \\
\text { MSW@ fraction } \\
0.17\left(\mathrm{Mt} \mathrm{yr}^{-1}\right)\end{array}$ & $\begin{array}{l}\text { Dissimilated DOC } \\
\text { fraction }(\mathrm{Mt}) @ 0.77\end{array}$ & $\begin{array}{l}\text { Fraction of } \mathrm{CH}_{4} \\
\left(\mathrm{Mt} \mathrm{yr}^{-1}\right)\end{array}$ & $\begin{array}{l}\text { Energy value } \\
\mathrm{PJ} \mathrm{yr}^{-1}\end{array}$ \\
\hline $23.5 \mathrm{Mt}(1997)$ & 20.0 & 3.40 & 2.61 & 1.73 & 86 \\
$56 \mathrm{Mt}(2010)$ & $50.4 @ 90 \%$ & 8.56 & 6.59 & 4.38 & 219 \\
\hline
\end{tabular}

DOC - degradable organic carbon.

into the atmosphere from waste dumps, either for flare or use as a source of energy. Systems need to be developed to collect methane and generate energy.

The total MSW generated in 1997 was $23.5 \mathrm{Mt}$. Based on the MSW collected in 5 large cities, the average MSW landfilled is about $85 \%$. The estimated energy potential of landfill gas in the year 1997 is about $86 \mathrm{PJ}$ (Table 12). It has been assumed that $90 \%$ of the MSW generated will be landfilled in 2010. The estimated energy potential of LFG in the year 2010 is 219 PJ.

Development of a landfill system for energy recovery would be a good option in warm climatic conditions of India. A system can be developed for successful collection and transportation of the MSW and efficient energy generation. An economic feasibility study has been done by IGIDR for Mumbai city [21]. For a total population of 10 million producing $1.82 \mathrm{Mt}$ of MSW per year, the net methane that can be produced is equivalent to about $8.5 \mathrm{GJ}$. In the proposed landfill system, the disposal cost of solid waste varies from 222 to
$566 \mathrm{Rst}^{-1}$. In the conventional waste management system the disposal cost is estimated to be $4054 \mathrm{Rs} \mathrm{t}^{-1}$.

\subsection{Industrial wastewater}

In addition to MSW, large quantity of wastewater is generated in certain industrial plants like breweries, sugar mills, distilleries, food-processing industries, tanneries, and paper and pulp industries. Out of this, food products and agro-based industries together account for $65-70 \%$ of the total industrial wastewater in terms of organic load [22]. Table 13 gives the estimate of wastewater generated in India by industries.

Conventional digesters such as anaerobic continuous stirred tank reactors (CSTR) have been used in India for many decades in sewage treatment plants for stabilization of the activated sludge and sewage solids. In recent times, the emphasis has shifted to high-rate biomethanation systems such as Upflow Anaerobic Sludge Blanket (UASB), fixed films, etc. 
Table 13

Energy potential from wastewater in India

\begin{tabular}{lcrrr}
\hline Industries & Wastewater produced $\left(\mathrm{Mm}^{3}\right)$ & COD of waste water $\left(\mathrm{kg} \mathrm{m}^{-3}\right)$ & Energy value of CH $4(\mathrm{TJ})^{\mathrm{a}}$ \\
\cline { 3 - 5 } & & & 1997 & $2010^{\mathrm{b}}$ \\
\hline Distillery & 6000 & 118.00 & 2973.60 & $105,138.00$ \\
Steel plants & $1,040,000$ & 0.60 & 936.00 & $92,664.00$ \\
Paper and allied products & 7200 & 0.72 & 7.73 & 765.55 \\
Sugar industry & 230 & 2.30 & 1.40 & 78.56 \\
Cotton & 1550 & 0.60 & 0.16 & 138.11 \\
Fertilizers & 52 & 2.00 & 0.01 & 15.44 \\
Refinery & 15 & 0.30 & 0.42 & 0.67 \\
Dairy & 206 & 1.35 & 0.03 & 41.38 \\
Pharmaceuticals & 56 & 0.39 & 0.01 & 3.24 \\
Coffee & 1.3 & 2.80 & 9.62 & 0.55 \\
Edible oil & 1425 & 4.50 & $3,929.76$ & 952.26 \\
Total & & & & $199,797.75$ \\
\hline
\end{tabular}

Source: $[25,26]$.

Notes: The IPCC default value of $20 \%$ is considered as the fraction of wastewater treated in anaerobic systems. For distillery, $56 \%$ is considered based on literature.

${ }^{a}$ Methane producing capacity of $0.15 \mathrm{~kg} \mathrm{CH}_{4} / \mathrm{kg} \mathrm{COD}$ for wastewater was considered.

${ }^{b}$ During 2010, the fraction of wastewater treated in anaerobic systems is assumed as $90 \%$ and wastewater production to increase proportionately to the population increase by 2010 .

The world's first full-scale UASB demonstration plant for municipal wastewater was built in Kanpur, Uttar Pradesh in 1989 under an IndoDutch project and has been in operation since then. The plant is designed to treat $5 \mathrm{Mlday}^{-1}$ domestic wastewater and the reported biogas yield is $0.1-0.15 \mathrm{~m}^{3} \mathrm{~kg}^{-1} \mathrm{COD}$ removed with a methane content of $75-80 \%$ [23].

\subsubsection{Characteristics of industrial water}

A total of 11 major industries have been considered for estimation of energy potential from industrial wastewater in India (Table 13). A total of $1.057 \mathrm{Tm}^{3}$ of wastewater is produced from these industries during 1997. The COD values of the wastewater generated were collected from published reports and books. The fraction of wastewater that was treated anaerobically for the different industries has been considered as $20 \%$ [24], except for distilleries, where $57 \%$ of the wastewater is treated in India (Table 13). An energy equivalent of 3.9 PJ can be produced by the industrial wastewater generated. For estimating the energy potential by 2010 , it is assumed that $90 \%$ of the wastewater will be anaerobically treated and wastewater production will increase in proportion to the population increase. Accordingly, the energy potential will be $200 \mathrm{PJ}$ (Table 13).

\section{Concluding remarks}

The energy value of agri-residues and other wastes, which include cattle dung, landfill gas (MSW) and industrial wastewater, is given in Table 14. The total energy potential in 1997 is estimated to be about $5.14 \mathrm{EJ}$, amounting to a little over a-third (at 39\%) of the total energy value of fossil fuels used during 1996-97 (13.23 EJ). The estimated total biomass energy potential in 2010 is $8.76 \mathrm{EJ}$. Fossil fuel substitution potential of biofuels is complex to determine, as it depends on: (i) the type of energy replaced (heat or electricity or mechanical energy), (ii) efficiency of fossil fuel system substituted, (iii) efficiency of bioenergy system and the conversion process, (iv) quantity of commercially available residue, and (v) technologies, costs and policies. 
Table 14

Energy potential of agri-residues and other wastes in India

\begin{tabular}{lrr}
\hline Source & \multicolumn{2}{c}{ PJ } \\
\cline { 2 - 3 } & 1997 & 2010 \\
\hline Crop residue & 4715 & 6565 \\
Dung & 336 & 374 \\
Landfill gas & 86 & 219 \\
Industrial wastewater & 4 & 200 \\
Biomass conservation & - & 506 \\
Biomass substitution & - & 900 \\
Total & 5141 & 8764 \\
\hline
\end{tabular}

The biofuels can be burnt as a source of heat energy, converted to gaseous fuels for heating or cooking and ultimately converted to electricity. For example, cattle dung can be dried and burnt directly as solid biofuel in a cook stove for heating or cooking or it can be converted to biogas through anaerobic digestion and used as gaseous fuel as a source of heat for cooking and finally, biogas can be converted to electricity. The fossil fuel substitution potential is likely to be different for different conversion process or end uses. Further, some of the crop residues as well as other non-plantation biomass may not be available for modern bioenergy or the quantity of non-plantation biomass that can be collected or utilized commercially is not known. It is important to note that technical potential estimated in this study has to be viewed with caution due to data limitations.

\section{Acknowledgements}

The authors thank the Swedish International Development Cooperation Agency (Sida) for the support provided for this work under the Asian Regional Research Programme in Energy, Environment and Climate (ARRPEEC).

\section{References}

[1] Ravindranath NH, Hall DO. Biomass, energy and environment: a developing country perspective from India. Oxford: Oxford University Press; 1995.
[2] Smith KR. Fuel combustion, air pollution exposure and health: the situation in developing countries. Annual Review of Energy and the Environment 1993;18: 529-56.

[3] Bhinde AD. Strategies for improvement of urban solid waste management in India. New Delhi: Touchstone Publishers and Printers; 1999.

[4] NCAER. Domestic fuel survey of household biogas plants set up during seventh five year plan. New Delhi: National Council for Applied Economic Research; 1985.

[5] Sarma EAS, Maggo JN, Sachdev AS. India's energy scenario in 2020. Proceedings of the 17th congress of the World Energy Council, Houston, USA; 1998.

[6] Battacharya SC, Abdul Salam P, Runqing H, Somashekar HI, Racelis DA, Rathnasiri PG, Yingyuad R. An assessment of the potential for non-plantation biomass resources in selected Asian countries for 2010. Biomass and Bioenergy, submitted for publication, doi:10.1016/ j.biombioe.2005.03.004.

[7] TSL. Statistical outline of India. Mumbai: Tata Services Limited, Dept. of Economics and Statistics; 1999.

[8] CMIE. Directory of Indian agriculture, Mumbai, India; 1997.

[9] CES. Annual report. Bangalore: Centre for Ecological Sciences, Indian Institute of Science; 1995.

[10] Brown LR, Kane H. Full house, reassessing the earth's population carrying capacity. London: Earthscan Publishers Ltd; 1995.

[11] FAO. http://www.fao.org. Rome: Food and Agriculture Organization (FAO); 1999.

[12] Anonymous. Basic animal husbandry statistics. New Delhi: Government of India; 1997.

[13] TERI. Tata energy data directory and yearbook 1996-97. New Delhi: Tata Energy Research Institute; 1997.

[14] MNES. Annual report of ministry of non-conventional energy sources. New Delhi: Govt. of India; 1998.

[15] Ravindranath NH, Usha Rao K, Natarajan B, Monga P. Renewable energy and environment: a policy analysis for India. New Delhi: Tata McGraw Hill; 2000.

[16] Dutt GS, Ravindranath NH. In. Johansson TB, Kelly H, Reddy AKN, Williams RH, editors. Renewable energy: sources for fuels and electricity. Island Press; 1993. p. $653-98$.

[17] MNES. Background information for conference of mayors and municipal commissioners. Urban and Industrial Energy Group; 1996.

[18] Ravindranath NH, Ramakrishna J. Energy options for cooking in India. Energy Policy 1997;25:63-75.

[19] Ahmed K, Jamwal N. A heap of problem: the problem of solid waste management is not just limited to the cities. Down to Earth January 2000:32-3.

[20] Anonymous. Housing and amenities: a database on housing and amenities for districts, cities and towns. Occasional Paper No. 5 of 1994. Demography, training and data dissemination division, Census of India, Office of the registrars general and census commissioners, New Delhi;1995. 
[21] Yedla S. http://www.ergweb.com/methane/pdf/yedla.pdf. Purpose built landfill system for the control of methane emissions from municipal solid waste. Mumbai: Indira Gandi Institute of Development Research.

[22] Pachauri RK, Sridharan PV. Solid wastes. In looking back to think ahead. New Delhi: Tata Energy Research Institute; 1998. p. 245-65.

[23] Khan A. Municipal wastewater treatment and energy recovery. In: Khanna S, Mohan K, editors. Wealth from waste. New Delhi: TERI; 1995. p. 195-214.
[24] IPCC. Revised 1996 IPCC guidelines for National Greenhouse Gas Inventories. Reference manual, vol. 3. Intergovernmental Panel for Climate Change.

[25] Hammer MJ, Hammer Jr. MK. Wastewater flows and characteristics. In water and wastewater technology. New Delhi: Prentice-Hall of India Pvt Ltd; 1998. p. 515.

[26] Trivedi PR, Raj G. Environmental industrial pollution control. In: Encyclopedia of environmental sciences, vol. 2. New Delhi: Akashdeep Publishing House; 1992. 